\title{
Antioxidant Properties of Two Wild Edible Mushrooms from Andhra Pradesh
}

\author{
Isha Sai ${ }^{\mathrm{a}, *}$ and R. Basavarju ${ }^{\mathrm{b}}$ \\ ${ }^{a}$ Department of Biosciences, Sri Sathya Sai Institute of Higher Learning, Anantapur Campus, 515001, AP, India \\ ${ }^{b}$ Department of Biosciences, Sri Sathya Sai Institute of Higher Learning, Prasanthi Nilayam Campus, 515134, AP, India \\ *CorrespondingauthorEmail: ishasai@sssihl.edu.in \\ (Submitted on May 2, 2020; Accepted on June 16, 2020)
}

\begin{abstract}
Investigations on the antioxidant potential of the methanolic extract of two wild edible mushrooms, namely Podaxis pistillaris (L. ex Pers.) Fr. and Termitomyces heimii Natarajan from Anantapur city in the arid zone of Andhra Pradesh, India has been included in this manuscript. Different concentrations $(0.25-1.25 \mathrm{mg} / \mathrm{mL})$ of extract were used for the assays. Out of the two mushrooms, Podaxis pistillaris show very high antioxidant properties in terms of total phenolic content $(93.08 \pm 2.02 \mathrm{mM}$ GAEs/g at $1.25 \mathrm{mg} / \mathrm{mL})$, DPPH radical scavenging activity $(91.69 \pm 0.15 \%$ at $1 \mathrm{mg} / \mathrm{mL}), \mathrm{ABTS}$ radical scavenging assay $(98.53 \pm 1.50 \%$ at $1 \mathrm{mg} / \mathrm{mL})$, ferric reducing antioxidant power assay $(36.50 \pm 0.13 \mu \mathrm{M}$ trolox equivalents $/ \mathrm{mg}$ at $1.25 \mathrm{mg} / \mathrm{mL})$ and ferrous-ion chelating activity $(89.50 \pm 0.46 \% \mathrm{at} 1.25 \mathrm{mg} / \mathrm{mL})$.
\end{abstract}

Keywords: Podaxis pistillaris, Termitomyces heimii, antioxidant activity, total phenolic content

\section{INTRODUCTION}

Antioxidants are known to possess radical scavenging capacity and to exert a potential protective effect against the free radical damage (Kris-Etherton et al., 2002). In biological systems, antioxidants protect against oxidative damage and help in preventing cardiovascular, neurological and/or carcinogenic diseases (Lanina et al., 2007). Antioxidants are considered as an important group of food additives that have the ability to protect against detrimental change of oxidized nutrients and hence they can be used to preserve or extend shelf-life of food (Andre et al., 2010).

Mushrooms are one of the natural sources of antioxidants and also of beneficial nutraceutical products which add to the endogenous protective system (Jayakumar, 2011; Reis et al., 2012; Atri et al., 2016; Mridu and Atri, 2017; Kore, 2020). Therefore, the investigations of the antioxidants especially from natural sources like dietary foods, vegetative mushrooms and others is the need of the hour (Lakhanpal et al., 2016; Acharya et al., 2017; Atri et al., 2019). Although numbers of cultivated and wild edible mushrooms were studied for their antioxidant properties from different geographic region of the world, this study is focused on mushrooms from arid region of Andhra Pradesh in India.

\section{MATERIALSAND METHODS}

Samples: The sporophores of two wild edible mushrooms, Podaxis pistillaris (L. ex Pers.) Fr.(Fig.1) and Termitomyces heimii, Natarajan (Fig.2) were collected after rainy season from the College Campus of Sri Sathya Sai Institute of Higher Learning at Anantapur, located in the semi-arid region of Andhra Pradesh, India. After collection the mushrooms were taxonomically worked out and identified after consulting the authentic literature (Natarajan, 1979; Atri et al., 2005; Mridu and Atri, 2015). The sporophores were subsequently cleaned, sliced into thin pieces and dried in an oven at $40^{\circ} \mathrm{C}$. Dried mushrooms were ground to a fine homogeneous powder using mortar and pestle and then powder was stored in an amber colored glass bottle at room temperature.

Sample preparation: Methanolic extract was prepared by sonicating and stirring $3 \mathrm{~g}$ of mushroom powder in $80 \%$ methanol at $150 \mathrm{rpm}$ for overnight at $25^{\circ} \mathrm{C}$ and then filtered through Whatman No.1 filter paper. The residue was reextracted with two additional proportion of $50 \mathrm{~mL}$ of methanol as described above. Filtrates were pooled, centrifuged and were evaporated at $40^{\circ} \mathrm{C}$ to dryness under reduced pressure using Heidolph Rotary evaporator. Extracts were stored at $-20^{\circ} \mathrm{C}$ until used.

Standards and reagents: The standards: Gallic acid (PubChem CID: 370), Trolox (PubChem CID: 40634), Folin-Ciocalteu reagent (FCR), 2,2'-Azino-bis

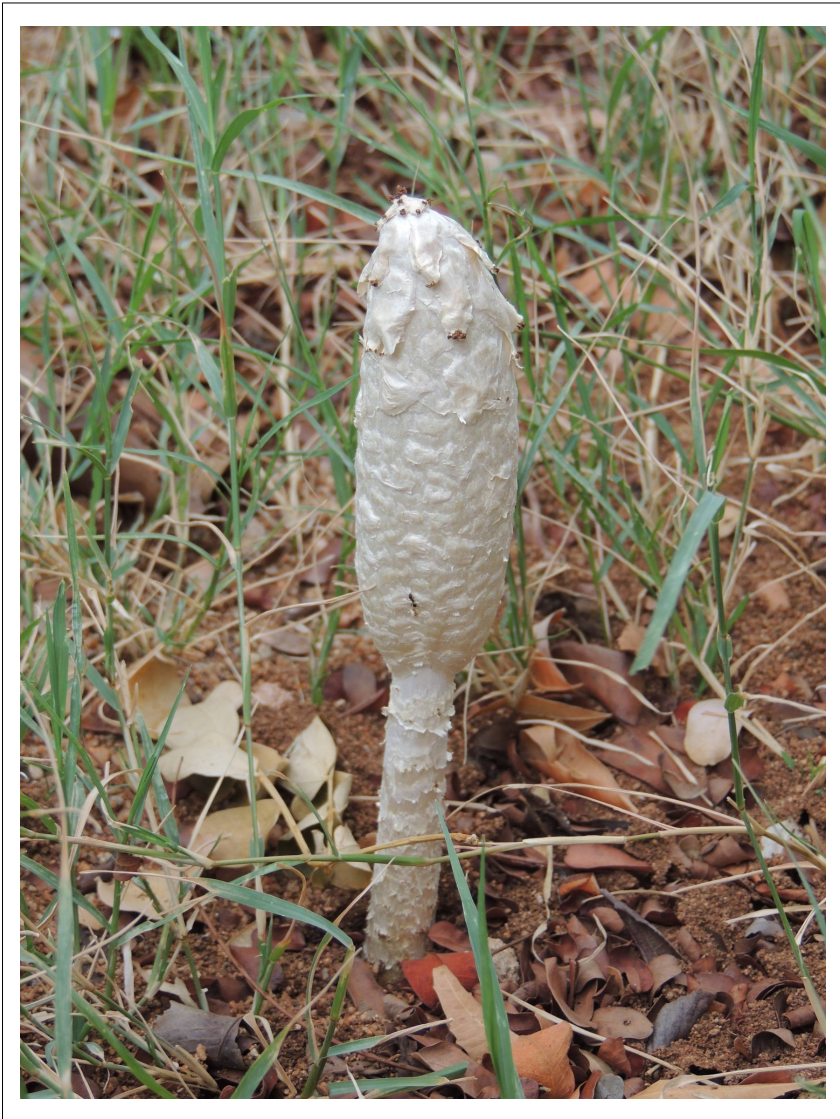

Fig.1. Podaxis pistillaris Field Photograph 


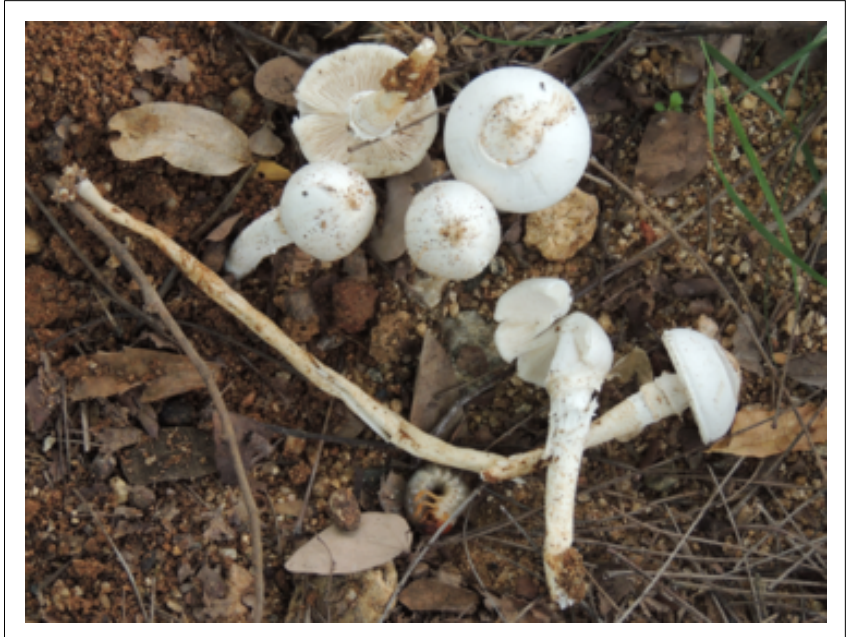

Fig. 2. Termitomyces heimii Field Photograph

(3-ethylbenzthiazoline-6-sulfonic acid) (ABTS) were purchased from Sigma Chemical Company. 2,2-Diphenyl-1picrylhydrazyl (DPPH), 2,4,6-Tri(2-pyridyl)-s-triazine (TPTZ), and ferrozine reagents were purchased from HiMedia Laboratories Private Limited. Sodium carbonate, disodium ethylenediaminetetraacetic acid $\left(\mathrm{Na}_{2}\right.$ EDTA), sodium acetate, ferric chloride, ferrous sulphate, potassium persulphate, hydrochloric acid, methanol and $95 \%$ ethanol, all these chemicals were of analytical grade and purchased from Merck Life Sciences Private Limited.

Determination of total phenolic content: Total phenolic content in mushrooms was determined using slightly modified method of Slinkard and Singleton (1977) with gallic acid as a standard. To various concentrations of mushroom extracts Folin-Ciocalteu reagent was added and mixed thoroughly. The saturated sodium carbonate was added to the mixture, incubated for two hours and the absorbance was measured at $760 \mathrm{~nm}$. The reduction of folin reagent by the sample was expressed as $\mathrm{mM}$ of gallic acid equivalent (GAE) per mg of extract. The concentration of phenolic compounds was calculated according to the equation obtained from graph of standard gallic acid.

Absorbance $=14.80^{*}$ Gallic acid $+0.1720 \quad\left(R^{2}=0.9936\right)$

DPPH radical scavenging activity: The free radical scavenging activity was determined spectrophotometrically by the DPPH assay (Blois, 1958) with slight modifications. Mushroom extracts of different concentrations were used for antioxidant activity. To $500 \mu \mathrm{L}$ of sample extract, $1.5 \mathrm{~mL}$ of $0.2 \mathrm{mM}$ DPPH was added and mixed thoroughly. Solution was kept for $30 \mathrm{~min}$ at room temperature and the absorbance was measured at $517 \mathrm{~nm}$. Methanol was used as control. The capability of scavenging the DPPH radical was calculated as percentage using the following formula:

$A b s_{\text {control }}$ is the initial concentration of the DPPH without sample and $A b s_{\text {sample }}$ is the absorbance of the remaining

$\%$ Radical Scavenging Activity (RSA) $=\left[1-\frac{A b s_{\text {sample }}}{A b s_{\text {control }}}\right]$ X 100 where, concentration of DPPH in the presence of extracts.

The extract concentration providing $50 \%$ radical scavenging activity $\left(\mathrm{EC}_{50}\right)$ was calculated from the graph of DPPH radical scavenging effect percentage against extract concentration. Trolox was used as an antioxidant standard for comparison of the activity.

ABTS radical scavenging assay: The spectrophotometric determination of $\mathrm{ABTS}^{+}$scavenging activity was analyzed according to the method of Re et al. (1999), with slight modification. The $\mathrm{ABTS}^{+}$radical was prepared by mixing $7 \mathrm{mM}$ ABTS stock solution with $2.45 \mathrm{mM}$ potassium per sulphate $(1 / 1, v / v)$ and the mixture was left for $12-16 \mathrm{hrs}$ at room temperature. Before usage, the $\mathrm{ABTS}^{+}$radical solution was diluted with 95\% ethanol (approx. 1:40) to obtain an absorbance of $0.7 \pm 0.02$ units at $734 \mathrm{~nm}$. Ethanol was used a blank. Then, $1 \mathrm{~mL}$ of $\mathrm{ABTS}^{+}$radical solution was added to $1 \mathrm{~mL}$ of sample extracts of various concentrations and the absorbance was measured at $734 \mathrm{~nm}$. The scavenging capability of $\mathrm{ABTS}^{+}$was calculated using the following equation:

$\% \mathrm{ABTA}^{+}$Scavenging Activity $=\left[1-\frac{A b s_{\text {sanple }}}{A b s_{\text {contol }}}\right] \times 100$ where,

Trolox was used as an antioxidant standard for comparison of the activity and was expressed as $\mu \mathrm{M}$ of Trolox Equivalent Antioxidant Capacity (TEAC) per mg of extract.

FRAP assay: The ferric reducing antioxidant power (FRAP) method is based (Benzie and Strain, 1996; Benzie and Szeto, 1999) on the reduction of a ferroin analog, the $\mathrm{Fe}^{3+}$ complex of tripyridyltriazine $\left[\mathrm{Fe}(\mathrm{TPTZ})_{3^{+}}\right]$, to the intensely blue coloured $\mathrm{Fe}^{2+}$ complex $\mathrm{Fe}(\mathrm{TPTZ})_{2+}$ by antioxidants in acidic medium. Antioxidant activity in mushroom samples was measured using modified method. The oxidant in this assay was prepared by mixing acetate buffer (pH 3.6), 10mM TPTZ in $40 \mathrm{mM} \mathrm{HCl}$ and $20 \mathrm{mM} \mathrm{FeCl}_{3}$ in a ratio of $10: 1: 1(\mathrm{v} / \mathrm{v} / \mathrm{v})$ and was called as "FRAP reagent". Freshly prepared $1.5 \mathrm{~mL}$ of FRAP reagent was added to $500 \mu \mathrm{L}$ of sample extracts of different concentrations and was vortexd thoroughly. Obtained mixture was stirred in shaking water bath at $37^{\circ} \mathrm{C}$ and absorbance was measured at $593 \mathrm{~nm}$. FRAP reagent was used as blank. Trolox was used to obtain the standard curve and the FRAP value of sample was expressed as $\mu \mathrm{M}$ of trolox equivalent per mg of extract. The FRAP value of sample in micro molar was calculated using the following formula:

FRAP value of sample $(\mu \mathrm{M})=\frac{A b s \text { (sample) } X \text { FRAP value of std. }(\mu m)}{A b s(\text { std. })}$

Ferrous-ion chelating activity: Ferrous chelating ability (FCA) in mushrooms was determined using modified method of Dinis et al. (1994). To the mushroom extract of various concentrations $100 \mu \mathrm{L}$ of $2 \mathrm{mM} \mathrm{FeSO}_{4}$ was added and mixed thoroughly. The reaction was then initiated by the addition of $100 \mu \mathrm{L}$ of $5 \mathrm{mM}$ Ferrozine. The solution was left at room 
temperature for $10 \mathrm{~min}$ and absorbance was measured at $562 \mathrm{~nm}$. The inhibition percentage of ferrozine-Fe ${ }^{2+}$ complex formation was calculated by using the formula given below:

$$
\% \text { Ferrous Chelating Ability }=\left[1-\frac{A b s_{\text {sample }}}{A b s_{\text {control }}}\right] \times 100 \text { where, }
$$

$A b s_{\text {control }}$ is the absorbance of complex formation molecules which is magenta in colour and $A b s_{\text {sample }}$ is the absorbance of the sample extract. EDTA was used as a standard. $\mathrm{EC}_{50}$ value (mg extract $/ \mathrm{mL}$ ) is the effective concentration at which ferrous ion were chelated by $50 \%$ and was obtained by interpolation from linear regression analysis.

Statistical analysis: Each sample was assayed with three replicates and all the assays were performed in triplicate. The results were expressed as mean \pm standard deviation $(n=3)$. The experiment data was subjected to one-way analysis of variance (ANOVA) for completely randomized design to determine the least significant difference amongst mean at the $5 \%$ level of significance.

\section{RESULTS AND DISCUSSION}

Extraction yield: Solubility of antioxidants is usually affected by the polarity of the solvent(s) used. Solvents such as methanol, ethanol, acetone, ethyl acetate, water and their combinations have also been used for extraction of antioxidant compounds. In the present study methanol was used as extraction solvent. The yield obtained from methanolic extracts of two edible wild mushrooms varied considerably. The highest yield was obtained from Podaxis pistillaris extract $(38.44 \pm 1.57 \% \mathrm{w} / \mathrm{w})$ followed by the extract of Termitomyces heimii $(34.44 \pm 1.92 \% \mathrm{w} / \mathrm{w})$.

Total phenolic content: Total polyphenols are the major naturally occurring antioxidant components found in wild edible mushrooms. In this study, the total phenolic content of mushrooms extract was tested using the concentrations ranging from $0.25-1.25 \mathrm{mg} / \mathrm{mL}$. The results obtained are expressed in mM GAEs/g of dry mushroom extract (Table 1). The value of phenolic compounds found in methanolic extract of Podaxis pistillaris and Termitomyces heimii were $83.55 \pm 3.72$ and $24.84 \pm 3.50 \mathrm{mM} \mathrm{GAEs} / \mathrm{g}$, respectively at $1 \mathrm{mg} / \mathrm{mL}$ concentration.

As compared the total phenolic content reported in ethanolic and aqueous extracts of Pleurotus sajor-caju was $9.48 \pm 0.85$ and $10.4 \pm 1.37 \mathrm{mg}$ GAEs $/ \mathrm{g}$, respectively at $16 \mathrm{mg} / \mathrm{mL}$ concentration (Kanagasabapathy et al., 2011) and in case of Pleurotus ostreatus it is reported to be $30.93 \pm 1.92$ and 42.47 $\pm 2.27 \mathrm{mg}$ GAEs $/ \mathrm{g}$, respectively (Chirinang and Intarapichet, 2009). At $10 \mathrm{mg} / \mathrm{mL}$ concentration, the aqueous extract of Pleurotus porrigens is reported to contain $5.04 \pm 41.18 \mathrm{mg}$ GAEs/g phenolic content (Yim et al., 2012).

In the methanolic extract of Podaxis pistillaris (at $1.25 \mathrm{mg} / \mathrm{L}$ ) evaluated presently very high phenolic content $(93.08 \pm 2.02$ $\mathrm{mM}$ GAEs/g) has been documented as compared to the reported values of phenolic content in the ethanolic extract of Trametes versicolor $(9.58 \pm 1.59 \mathrm{mg}$ GAEs/g), Polyporus fomentarius (47.29 $\pm 1.37 \mathrm{mg} \mathrm{GAEs} / \mathrm{g})$, Cantharellus cibarius $(31.48 \pm 1.57 \mathrm{mg}$ GAEs/g) and Lactarius deliciosus (51.27 $\pm 1.44 \mathrm{mg}$ GAEs/g) by Orhan and Üstün (2011). Similarly Arbaayah and Umi (2013) evaluated $40.51 \pm 0.72$ $\mathrm{mg}$ Tannic Acid Equivalents (TAEs)/g DW in Schizophyllum commune, $51.94 \pm 0.67 \mathrm{mg}$ TAEs/g in Pleurotus djamor var. djamor and $39.36 \pm 0.19 \mathrm{mg}$ TAEs/g in Pleurotus pulmonarius. In the methanolic extract of Agaricus bisporus (85.45 $\pm 0.36 \mathrm{mg}$ Pyrocatechol Equivalents (PEs) $/ \mathrm{g})$ ), A.bitorquis (33.15 $\pm 0.10 \mathrm{mg} \mathrm{PEs} / \mathrm{g})$ and also in A.essettei (53.45 $\pm 0.20 \mathrm{mg}$ PEs/g) much less amount of phenolic content has been evaluated by Ozturk et al. (2011) in comparison to the net amount of this component evaluated in Podaxis pistillaris during the present investigations.

DPPH radical scavenging activity: The method of scavenging "stable" DPPH free radical can be used to evaluate the antioxidant activity of extracts or specific compounds. The per cent scavenging activity of DPPH radical observed presently using methanolic extracts of mushrooms at various concentrations is given in tabulated form (Table 2). As is evident from the values obtained the radical scavenging activity of the methanolic extracts of Podaxis pistillaris was found to be higher in comparison to the scavenging activity of the methanolic extracts of Termitomyces heimii. At $1 \mathrm{mg} / \mathrm{mL}$, Podaxis pistillaris exhibited very high radical scavenging activity (91.69 \pm $0.15 \%$ ) which is significantly higher in comparison to the number of such reports from elsewhere on other mushrooms. Sarikurkcu et al. (2010) while working with Amanita caesarea (79.4 $\pm 1.4 \%)$, Clitocybe geotrope $(64.8 \pm 1.9 \%)$ and Leucoagaricus pudicus $(64.6 \pm 0.8 \%)$ reported much less scavenging activity when $-20 \mathrm{mg} / \mathrm{mL}$ methanolic extracts of these mushrooms was used for evaluation. Similarly Orhan and Üstün (2011) also reported lower value of the scavenging activity of ethanolic extracts $(5 \mathrm{mg} / \mathrm{mL})$ of Cantharellus

Table 1. Concentrations of total phenolics (mM GAEs/g) in methanolic extracts.

\begin{tabular}{|c|c|c|c|c|c|c|}
\hline \multirow{3}{*}{ Sample } & \multirow{3}{*}{$\begin{array}{l}\text { Sample } \\
\text { ID }\end{array}$} & \multicolumn{5}{|c|}{ Total phenolics $^{\mathrm{a}}$ (mM GAEs $/ \mathrm{g}$ of extract) } \\
\hline & & \multicolumn{5}{|c|}{ Sample Concentration (mg/ml) } \\
\hline & & 0.25 & 0.50 & 0.75 & 1.00 & 1.25 \\
\hline Podaxis pistillaris & PP & $17.71 \pm 1.16$ & $41.95 \pm 2.16$ & $65.77 \pm 2.41$ & $83.55 \pm 3.72$ & $93.08 \pm 2.02$ \\
\hline $\begin{array}{l}\text { Termitomyces } \\
\text { heimii }\end{array}$ & $\mathrm{TH}$ & $0.00 \pm 0.41$ & $07.18 \pm 1.54$ & $16.49 \pm 2.69$ & $24.84 \pm 3.50$ & $30.38 \pm 3.56$ \\
\hline
\end{tabular}


Table 2. DPPH radical scavenging activity (\%) of the methanolic extracts of mushrooms at different concentrations ${ }^{\mathrm{a}}$

\begin{tabular}{|c|c|c|c|c|c|c|}
\hline \multirow{2}{*}{ Sample } & \multirow{2}{*}{$\begin{array}{c}\text { Sample } \\
\text { ID }\end{array}$} & \multicolumn{5}{|c|}{ Sample Concentration $(\mathrm{mg} / \mathrm{ml})$} \\
\hline & & 0.25 & 0.50 & 0.75 & 1.00 & 1.25 \\
\hline Podaxis pistillaris & PP & $34.07 \pm 2.57$ & $66.40 \pm 4.42$ & $90.28 \pm 1.03$ & $91.69 \pm 0.15$ & $91.45 \pm 0.38$ \\
\hline \multirow{2}{*}{$\begin{array}{l}\text { Termitomyces } \\
\text { heimii }\end{array}$} & $\mathrm{TH}$ & $7.15 \pm 1.26$ & $11.43 \pm 1.85$ & $16.07 \pm 2.23$ & $21.15 \pm 3.60$ & $23.27 \pm 4.37$ \\
\hline & & \multicolumn{5}{|c|}{ Standard Concentration $(\mu \mathrm{M})$} \\
\hline Standard & & 12.5 & 25.0 & 37.5 & 50.0 & 62.5 \\
\hline $\operatorname{Trolox}^{\mathrm{b}}$ & & $15.97 \pm 0.83$ & $33.84 \pm 1.20$ & $49.30 \pm 1.52$ & $69.87 \pm 0.72$ & $88.96 \pm 1.66$ \\
\hline
\end{tabular}

cibarius (59.87 $\pm 2.34 \%)$, Lactarius deliciosus (62.41 $\pm 0.67 \%)$, Trametes versicolor $(28.69 \pm 0.50 \%)$ and Polyporus volvatus $(84.29 \pm 0.67 \%)$. However, in comparison the radical scavenging activity of methanolic extracts $(300 \mathrm{mg} / \mathrm{mL})$ of stipe $(85.5 \%)$ and pileus $(84.49 \%)$ of Russula griseocarnosa is not exactly the same but almost near to the scavenging activity of the methanolic extract of the presently evaluated mushrooms (Chen et al., 2010). Kalyoncu et al. (2010) also evaluated the ethanolic extracts $(1 \mathrm{mg} / \mathrm{mL})$ of Omphalotus olearius $(60.25 \%)$, Morchella esculenta (27.41\%), Ganoderma lucidum (10.75\%) and Lentinula edodes (6.20\%) and documented very low percentage of radical scavenging activity in comparison to the presently evaluated mushrooms.

In present study, lower DPPH $\mathrm{EC}_{50}$ values (Table 6) for Podaxis pistillaris $(0.486 \mathrm{mg} / \mathrm{mL})$ indicates that this mushroom have better antioxidant properties than the other mushrooms. $\mathrm{EC}_{50}$ values in scavenging the $\mathrm{DPPH}$ radical for methanolic extract of stipe $(1.93 \pm 0.03 \mathrm{mg} / \mathrm{mL})$, cap $(1.77 \pm 0.03 \mathrm{mg} / \mathrm{mL})$ and gills $(0.82 \pm 0.02 \mathrm{mg} / \mathrm{mL})$ of Agaricus bisporus as reported by Savoie et al. (2008) is much less in comparison to $\mathrm{DPPH} \mathrm{EC}_{50}$ values obtained for Podaxis pistillaris during the present investigations. Similarly, Ozturk et al. (2011) also reported lower $\mathrm{EC}_{50}$ values of $\mathrm{DPPH}$ scavenging effect obtained from methanolic extract for Agaricus bisporus $(0.988 \pm 0.13 \mathrm{mg} / \mathrm{mL}), \quad$ A. bitorquis $(0.590 \pm 0.31 \mathrm{mg} / \mathrm{mL})$ and $A$. essettei $(0.921 \pm 0.07 \mathrm{mg} / \mathrm{mL})$ when compared with the similar such observations made presently while working with the two wild edible mushrooms.

ABTS radical scavenging assay: Antioxidant activities using the sporophores of Podaxis pistillaris and Termitomyces heimii determined as per cent scavenging activity of $\mathrm{ABTS}^{+}$radical are presented in Table 3. As is apparent from the generated data given in the table, at $1.25 \mathrm{mg} / \mathrm{mL}$ concentration, the methanolic extract of Podaxis pistilaris exhibited highest RSA $(98.83 \pm 0.91 \%)$ when reacted with $\mathrm{ABTS}^{+}$radical in comparison to Termitomyces heimii $(61.00 \pm 9.41 \%)$.

During present study, the evaluated per cent scavenging activity of Podaxis pistillaris at $1 \mathrm{mg} / \mathrm{mL}$ concentration is significantly higher $(98.53 \pm 1.50 \%)$ when compared with the $\mathrm{ABTS}^{+}$radical scavenging activities reported when the ethanolic extract of Omphalotus olearius (88.01\%), Morchella esculenta (87.07\%), Ganoderma lucidum $(22.28 \%)$ and Lentinula edodes (43.00\%) was used (Kalyoncu et al., 2010). In the ethanolic extract of Pleurotus tuber-regium at $5 \mathrm{mg} / \mathrm{mL}$ concentration Lin et al., (2014) reported $13.54 \pm 2.51 \% \mathrm{ABTS}^{+}$radical scavenging activity which is much less in comparison to what has been obtained during the present investigation while working with Podaxis pistillaris and Termitomyces heimii. In aqueous extract of Pleurotus porrigens $77.48 \pm 5.02 \% \mathrm{ABTS}^{+}$radical scavenging activity has been documented by Yim et al. (2012) which is much on the higher side in comparison to what has been reported by Lin et al., (2014) in the ethanolic extract of Pleurotus tuber-regium but it is still less in comparison to $\mathrm{ABTS}^{+}$radical scavenging activity of methanolic extract of Podaxis pistillaris evaluated presently.

$\mathrm{The}_{\mathrm{ABTS}}^{+}$radical scavenging activity of methanolic extract is also expressed as Trolox Equivalent Antioxidant Capacity (TEAC) and defined as the $\mu$ mol of Trolox equivalents (TEs) per milligram of mushroom extract. In terms of TEAC, the Podaxis pistillaris and Termitomyces heimii revealed highest

Table 3. $\mathrm{ABTS}^{+}$radical scavenging activity (\%) of the methanol extracts of mushrooms at different concentrations ${ }^{\mathrm{a}}$

\begin{tabular}{|c|c|c|c|c|c|c|}
\hline \multirow{2}{*}{ Sample } & \multirow{2}{*}{$\begin{array}{c}\text { Sample } \\
\text { ID }\end{array}$} & \multicolumn{5}{|c|}{ Sample Concentration $(\mathrm{mg} / \mathrm{ml})$} \\
\hline & & 0.25 & 0.50 & 0.75 & 1.00 & 1.25 \\
\hline \multirow{3}{*}{$\begin{array}{l}\text { Podaxis pistillaris } \\
\text { Termitomyces } \\
\text { heimii }\end{array}$} & PP & $39.14 \pm 4.04$ & $70.36 \pm 2.18$ & $89.97 \pm 1.87$ & $98.53 \pm 1.50$ & $98.83 \pm 0.91$ \\
\hline & $\mathrm{TH}$ & $16.81 \pm 5.36$ & $27.20 \pm 7.50$ & $43.55 \pm 7.64$ & $52.76 \pm 9.18$ & $61.00 \pm 9.41$ \\
\hline & & \multicolumn{5}{|c|}{ Standard Concentration $(\mu \mathrm{M})$} \\
\hline Standard & & 1.875 & 3.750 & 5.625 & 7.500 & 9.375 \\
\hline Trolox ${ }^{b}$ & & $12.36 \pm 2.44$ & $28.15 \pm 0.88$ & $52.32 \pm 2.71$ & $75.28 \pm 1.82$ & $80.57 \pm 1.16$ \\
\hline
\end{tabular}


value i.e., 0.550 and $0.561 \mu \mathrm{mol} \mathrm{TEs} / \mathrm{mg}$, respectively. Kanagasabapathy et al. (2011) while working with the aqueous and ethanolic extract of Pleurotus sajor-caju evaluated the scavenging activity at $29.45 \pm 3.07$ and $16.58 \pm$ $3.09 \mu \mathrm{mol} \mathrm{TEs} / \mathrm{g}$, respectively which is much on the lower side in comparison to its value documented in the methanolic extract of Podaxis pistillaris and Termitomyces heimii. In the ethanolic extract of Lentinula edodes also Choi et al. (2006) evaluated $7.6 \mathrm{mg}$ Ascorbic acid Equivalents (AEs)/100g scavenging activity when treated at $100^{\circ} \mathrm{C}$ and $10.8 \mathrm{mg}$ $\mathrm{AEs} / 100 \mathrm{~g}$ scavenging activity when treated at $121^{\circ} \mathrm{C}$ for $30 \mathrm{~min}$ which is quite less in comparison to the presently evaluated mushrooms.

In the data presented in table 6, the antioxidant properties have been expressed as the $\mathrm{EC}_{50}$ values for reducing power, DPPH, ABTS scavenging effects and ferrous chelating ability obtained from methanolic extracts of each mushroom. The effectiveness of antioxidant properties is inversely correlated with their $\mathrm{EC}_{50}$ values. While working with Agaricus bisporus, Savoie et al. (2008) evaluated the $\mathrm{EC}_{50}$ values in scavenging the activity of ABTS radical in the methanolic extract of stipe $(2.95 \pm 0.08 \mathrm{mg} / \mathrm{mL})$, cap $(2.90 \pm 0.11 \mathrm{mg} / \mathrm{mL})$ and gills $(1.16 \pm 0.02 \mathrm{mg} / \mathrm{mL})$ separately. Ozturk et al. (2011) also evaluated the $\mathrm{EC}_{50}$ values of ABTS scavenging effect obtained from methanolic extract for Agaricus bisporus $(0.241 \pm 0.07 \mathrm{mg} / \mathrm{mL})$, A. bitorquis $(0.158 \pm 0.03 \mathrm{mg} / \mathrm{mL})$ and A. essettei $(0.347 \pm 1.02 \mathrm{mg} / \mathrm{mL})$. As compared during the present study, lower ABTS $\mathrm{EC}_{50}$ values were obtained for Podaxis pistillaris $(61.57 \mu \mathrm{g} / \mathrm{mL})$ and Termitomyces heimii $(94.78 \mu \mathrm{g} / \mathrm{mL})$ which clearly indicates that these mushrooms have better antioxidant properties in comparison to Agaricus bisporus, A. bitorquis and A. essettei.

FRAP assay: The reducing power (FRAP) assay, using methanolic extracts of Podaxis pistillaris and Termitomyces heimii in different concentrations ranging from 0.25-1.25 $\mathrm{mg} / \mathrm{mL}$, when performed, the FRAP value was found to increase with the increasing concentration of the extracts used (Table 4). The extract of Podaxis pistillaris gave $35.02 \pm 0.20$ $\mu \mathrm{M}$ TEs/mg reducing power which is much higher than $12.13 \pm 2.07 \mu \mathrm{M}$ TEs/mg reducing power measured with the methanolic extract of Termitomyces heimii at a concentration of $1 \mathrm{mg} / \mathrm{mL}$.
During the present study, the mushroom sample of Podaxis pistillaris from Anantapur displayed high ferric reducing antioxidant power $(36.50 \pm 0.13 \mu \mathrm{M} \mathrm{TEs} / \mathrm{mg})$ at $1.25 \mathrm{mg} / \mathrm{mL}$ concentration compared to the FRAP values evaluated in number of mushrooms except Suillus luteus $(53.52 \mu \mathrm{M} / \mathrm{mg})$. Keles et al. (2011) evaluated the reducing power of methanolic extract of Agaricus bisporus (12.17 $\mu \mathrm{mol} / \mathrm{mg})$, Pleurotus ostreatus $(2.38 \mu \mathrm{mol} / \mathrm{mg})$, Hydnum repandum $(0.14 \mu \mathrm{mol} / \mathrm{mg})$, Lactarius deliciosus $(2.67 \mu \mathrm{mol} / \mathrm{mg})$ and Russula nigricans $(23.60 \mu \mathrm{mol} / \mathrm{mg})$. The values reported for different evaluated mushroom samples were substantially on the lower side in comparison to the presently obtained values. Even the methanolic extract of Lactarius sanguifluus $(2.12 \pm 0.46 \mu \mathrm{mol} \mathrm{TEs} / 100 \mathrm{~g})$, Russula delica $(1.18 \pm 0.30 \mu \mathrm{mol}$ TEs/100g) and Suillus bellinii $(4.54 \pm 0.16 \mu \mathrm{mol}$ TEs/100g) exhibited much lower FW FRAP values (Kalogeropoulos et $a l ., 2013)$. Reducing power assay of ethanolic and aqueous extracts $(16 \mathrm{mg} / \mathrm{ml})$ of Pleurotus sajor-caju was evaluated as $26.29 \pm 2.82$ and $35.06 \pm 0.86 \mu \mathrm{mol}$ FEs/g (Kanagasabapathy et al., 2011) and that of Pleurotus ostreatus was evaluated $(20 \mathrm{mg} / \mathrm{mL})$ as 1.61 and $4.38 \mu \mathrm{mol} \mathrm{Fe}^{2+} / \mathrm{mL}$, respectively (Chirinang and Intarapichet, 2009). Yim et al. (2012) reported $6.71 \pm 0.61 \mu \mathrm{mol} \mathrm{FEs} / 100 \mathrm{~g}$ FRAP assay in the aqueous extract of Pleurotus porrigens.

Ferrous-ion chelating activity: In this assay, the chelating agents disrupt the Ferrozine-Fe ${ }^{2+}$ complex, thereby, decreasing the intensity of purple colour. The rate of colour reduction which is measured at $550 \mathrm{~nm}$ is used for the estimation of the chelating activity. A lower absorbance indicates high chelating ability.

The chelating ability of the methanolic extracts of Podaxis pistillaris was found to be higher than the chelating ability of the methanolic extract of Termitomyces heimii (Table 5). At $1.25 \mathrm{mg} / \mathrm{mL}$, the methanolic extracts of Podaxis pistillaris and Termitomyces heimii was found to chelate $89.50 \pm 0.46 \%$ and $81.43 \pm 1.90 \%$ ferrous-ions, respectively. Ferrous chelating ability of both the mushrooms has been found to be relatively higher when compared to the chelating ability of some of the mushrooms evaluated in this regard. The ferrous chelating ability when methanolic extract was used at $10 \mathrm{mg} / \mathrm{mL}$ concentration has been reported at $62 \pm 7.8 \%$ in Agaricus blazei (Soares et al., 2009) and 60.68\% in Pleurotus

Table 4. FRAP value ( $\mu \mathrm{M}$ Trolox Equivalents/mg) of the methanolic extracts of mushrooms at different concentrations $\mathrm{s}^{\mathrm{a}}$ using FRAP assay.'

\begin{tabular}{|c|c|c|c|c|c|c|}
\hline \multirow{3}{*}{ Sample } & \multirow{3}{*}{$\begin{array}{c}\text { Sample } \\
\text { ID }\end{array}$} & \multicolumn{5}{|c|}{ FRAP Value $^{\mathrm{a}}\left(\mu \mathrm{M} \mathrm{TEs}^{\mathrm{b}} / \mathrm{mg}\right.$ of extract $)$} \\
\hline & & \multicolumn{5}{|c|}{ Sample Concentration $(\mathrm{mg} / \mathrm{ml})$} \\
\hline & & 0.25 & 0.50 & 0.75 & 1.00 & 1.25 \\
\hline Podaxis pistillaris & PP & $12.89 \pm 0.40$ & $23.28 \pm 0.76$ & $31.20 \pm 0.43$ & $35.02 \pm 0.20$ & $36.50 \pm 0.13$ \\
\hline $\begin{array}{l}\text { Termitomyces } \\
\text { heimii }\end{array}$ & $\mathrm{TH}$ & $3.27 \pm 0.65$ & $6.33 \pm 1.34$ & $9.63 \pm 1.94$ & $12.13 \pm 2.07$ & $13.97 \pm 2.42$ \\
\hline \multicolumn{7}{|c|}{ Standard Concentration $(\mu \mathrm{M})$} \\
\hline Standard & & 1.875 & 3.750 & 5.625 & 7.500 & 9.375 \\
\hline $\operatorname{Trolox}^{\mathrm{c}}(A b s)$ & & $0.07 \pm 0.0$ & $0.19 \pm 0.02$ & $0.29 \pm 0.0$ & $0.38 \pm 0.0$ & $0.45 \pm 0.01$ \\
\hline
\end{tabular}


Table 5. Metal chelating ability $(\%)$ of the methanolic extracts of mushrooms at different concentrations ${ }^{\mathrm{a}}$

\begin{tabular}{|c|c|c|c|c|c|c|}
\hline \multirow{2}{*}{ Sample } & \multirow{2}{*}{$\begin{array}{l}\text { Sample } \\
\text { ID }\end{array}$} & \multicolumn{5}{|c|}{ Sample Concentration $(\mathrm{mg} / \mathrm{ml})$} \\
\hline & & 0.25 & 0.50 & 0.75 & 1.00 & 1.25 \\
\hline Podaxis pistillaris & PP & $60.61 \pm 2.67$ & $78.08 \pm 1.77$ & $82.75 \pm 0.89$ & $87.51 \pm 0.29$ & $89.50 \pm 0.46$ \\
\hline \multirow{2}{*}{$\begin{array}{l}\text { Termitomyces } \\
\text { heimii }\end{array}$} & $\mathrm{TH}$ & $42.35 \pm 1.53$ & $64.57 \pm 4.57$ & $72.49 \pm 1.08$ & $78.91 \pm 0.63$ & $81.43 \pm 1.90$ \\
\hline & & \multicolumn{5}{|c|}{ Standard Concentration $(\mu \mathrm{M})$} \\
\hline Standard & & 100 & 125 & 150 & 175 & 200 \\
\hline EDTA $^{b}$ & & $24.66 \pm 0.69$ & $49.32 \pm 1.43$ & $61.56 \pm 0.60$ & $86.00 \pm 0.45$ & $98.49 \pm 0.85$ \\
\hline
\end{tabular}

ostreatus (Jayakumar et al., 2009). In comparison when $1 \mathrm{mg} / \mathrm{mL}$ concentration of the methanolic extract was used the ferrous ion chelating ability has been documented at $60.1 \pm 2.1 \%$ in Amanita caesarea, $28.0 \pm 0.2 \%$ in Clitocybe geotrope and $88.0 \pm 1.1 \%$ in Leucoagaricus pudicus (Sarikurkcu et al., 2010).

Orhan and Üstün (2011) also investigated the chelating abilities of ethanolic extracts of Polyporus radiatus $(18.05 \pm 1.32 \%)$, Lactarius deliciosus $(33.30 \pm 0.54 \%)$ and Polyporus badius $(23.22 \pm 0.04 \%)$ using $5 \mathrm{mg} / \mathrm{mL}$ concentration in the extract. Similarly methanolic extracts of stipe and pileus of Russula griseocarnosa has been reported to chelate $74.4 \%$ and $79.2 \%$ of ferric ions, respectively when at $10 \mathrm{mg} / \mathrm{mL}$ concentration was used in the extract (Chen et al., 2010). Kalogeropoulos et al. (2013) while evaluating the methanolic extracts of Lactarius deliciosus $\left(52.3 \pm 2.8 \mu \mathrm{mol} \mathrm{Fe}{ }^{2+} / 100 \mathrm{~g}\right)$, L. sanguifluus $(49.8 \pm 5.7$ $\left.\mu \mathrm{mol} \mathrm{Fe}^{2+} / 100 \mathrm{~g}\right)$, L. semisanguifluus $(41.0 \pm 6.9 \mu \mathrm{mol}$

\section{CONCLUSION}

The results presented on the antioxidant activities of Podaxis pistillaris and Termitomyces heimii and the comparison of the results made with similar such findings in the literature it becomes clear that in comparison to the other mushrooms, $P$. pistillaris possesses significant antioxidant properties in terms of total phenolic content, scavenging of radicals, chelation of ferrous-ions and for reducing power assay. As the presence of total phenols is the main component responsible for the "antioxidant power" of the mushrooms, it was found that $P$. pistillaris contained $93.08 \pm 2.02 \mu \mathrm{M}$ gallic acid equivalents/gram of dry extract at $1.25 \mathrm{mg} / \mathrm{mL}$. The results of this study and the comparison of the results thereof indicate that the mushrooms are potential source of natural antioxidants and are best suited for use as dietary supplements, functional foods, and also for the development of nutraceuticals.

Table 6. Antioxidant activity in terms of $\mathrm{EC}_{50}$ values $^{\mathrm{a}}(\mathrm{mg} / \mathrm{ml}$ or $\mu \mathrm{g} / \mathrm{ml})$ of methanolic extracts of wild edible mushrooms for DPPH, ABTS ${ }^{+}$, FCA and FRAP assays.

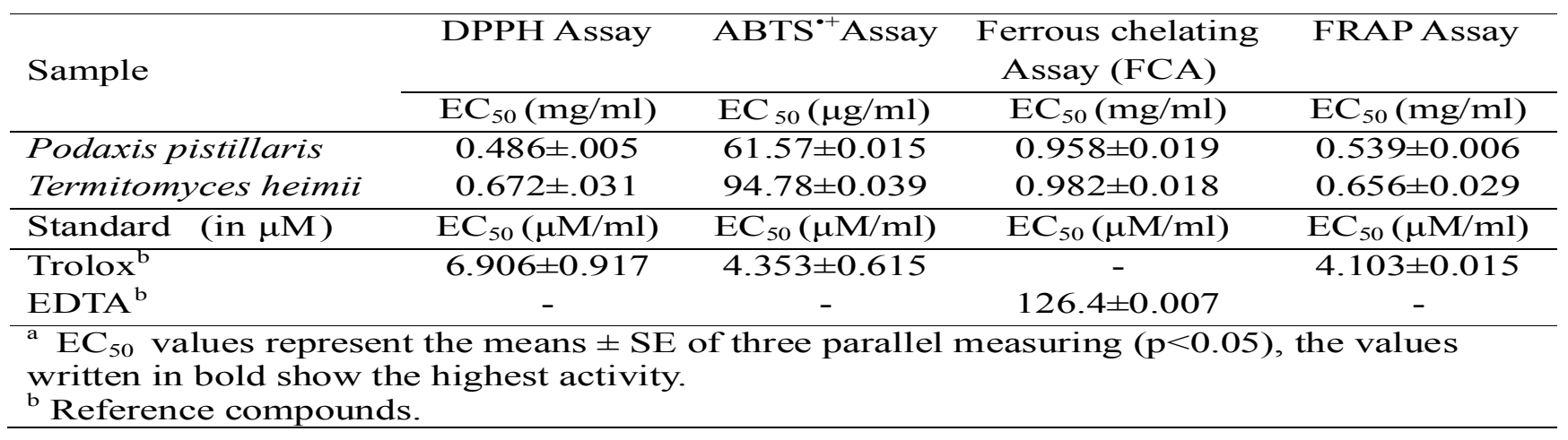

$\left.\mathrm{Fe}^{2+} / 100 \mathrm{~g}\right)$, Russula delica $\left(52.5 \pm 8.3 \mu \mathrm{mol} \mathrm{Fe}^{2+} / 100 \mathrm{~g}\right)$ and Suillus bellinii $\left(27.1 \pm 4.3 \mu \mathrm{mol} \mathrm{Fe} \mathrm{Fe}^{2+} / 100 \mathrm{~g}\right)$ documented the respective FW chelating values mentioned in parenthesis against the respective mushroom.

Presently chelated $\mathrm{EC}_{50}$ values for Podaxis pistillaris and Termitomyces heimii were evaluated at 0.95 and $0.98 \mathrm{mg} / \mathrm{mL}$. As compared Oke and Aslim (2011) reported the $\mathrm{EC}_{50}$ values of chelating abilities obtained from methanolic extracts for Pleurotus eryngii and Auricularia auricula-judae to be $0.42 \pm 0.03$ and $1.52 \pm 0.14 \mathrm{mg} / \mathrm{mL}$, respectively.

\section{ACKNOWLEDGEMENTS}

Authors would like to acknowledge UGC-SAP (DRS) and DST-FIST, Govt. of India for the infrastructural support to the Department of Biosciences, Sri Sathya Sai Institute of Higher Learning.

\section{REFERENCES}

Acharya, K., Khatua, S. and Ray, S. 2017. Quality assessment and antioxidants study of Pleurotus djmor (Rumph ex Fr.) Boedijn. Journal of Applied Pharmaceutical Science 7: 105-110. 
Andre, C., Castanheira, I., Cruz, J.M., Paseiro, P. and Sanches-Silva, A. 2010. Analytical strategies to evaluate antioxidants in food: A Review. Trends in Food Science \& Technology 21: 229-246.

Arbaayah, H. H. and Umi, K. Y. 2013. Antioxidant properties in the oyster mushrooms (Pleurotus spp.) and split gill mushroom (Schizophyllum commune) ethanolic extracts. Mycosphere 4: 661-673.

Atri, N.S., Kaur Amanjeet and Kour Harwinder 2005. Systematics and Sociobiology of Termitophilous Mushrooms from Punjab. In: The Fungi-Diversity and Conservation in India (Eds.: Dargan, J.S., Atri, N.S., and Dhingra, G.S.), P.p. 159-182. Bishen Singh Mahendra Pal Singh, Dehra Dun, Uttra Khand, India.

Atri, N.S., Sharma Samidha, Saini, Munruchi Kaur and Das Kanad. 2016. Researches on Russulaceous Mushrooms-An Appraisal. Kavaka 47: 63-82.

Atri, N.S., Sharma, Y.P., Sanjeev, K. and Mridu. 2019. Wild edible mushrooms of North west Himalaya: Their nutritional, nutraceutical and sociobiological aspects. In: Microbial diversity in Ecosystem Sustainability and Biotechnological Applications (Eds.: Satyanarayana, T. et al.) pp. 533-563. Springer Nature Singapore Pvt. Ltd.

Benzie, I. F. F. and Strain, J. J. 1996. The ferric reducing ability of plasma (FRAP) as a measure of "antioxidant power": The FRAP assay. Analytical Biochemistry 239: 70-76.

Benzie, I. F. F. and Szeto, Y. T. 1999. Total antioxidant capacity of teas by the ferric reducing/antioxidant power assay. Journal of Agriculture and Food Chemistry 47: 633-636.

Blois, M.S. 1958. Antioxidant determinations by the use of a stable free radical. Nature 181: 1199-1200.

Chen, X., Xia, L., Zhou, H. and Qiu, G. 2010. Chemical composition and antioxidant activities of Russula griseocarnosa sp. nov. Journal of Agricultural and Food Chemistry 58: 6966-6971.

Chirinang, P. and Intarapichet, K. 2009. Amino acids and antioxidant properties of the oyster mushrooms, Pleurotus ostreatus and Pleurotus sajor-caju. Science Asia 35: 326-331.

Choi, Y., Lee, S. M., Chun, J., Lee, H. B. and Lee, J. 2006. Influence of heat treatment on the antioxidant activities and polyphenolic compounds of Shiitake (Lentinula edodes) mushroom. Food Chemistry 99: 381-387.

Dinis, T. C. P., Madeira, V. M. C. and Almeida, L. M. 1994. Action of phenolic derivatives (acetaminophen, salicylate, and 5- amino salicylate) as inhibitors of membrane lipid peroxidation and as peroxyl radical scavengers. Archives of Biochemistry and Biophysics 315: 161-169.
Jayakumar, T., Thomas, P. A. and Geraldine, P. 2009. In-vitro antioxidant activities of an ethanolic extract of the oyster mushroom, Pleurotus ostreatus. Innovative Food Science and Emerging Technologies 10: 228234.

Jayakumar, T., Thomas, P. A., Sheu, J. R. and Geraldine, P. 2011. In-vitro and in-vivo antioxidant effects of the oyster mushroom Pleurotus ostreatus. Food Res. Int. 44: 851-861.

Kalogeropoulos, N., Yanni, A. E., Koutrotsios, G. and Aloupi, M. 2013. Bioactive micro constituents and antioxidant properties of wild edible mushrooms from the island of Lesvos, Greece. Food and Chemical Toxicology 55:378-385.

Kalyoncu, F., Oskay, M. and Kayalar, H. 2010. Antioxidant activity of the mycelium of 21 wild mushroom species. Mycology 1: 195-199.

Kanagasabapathy, G., Malek, S. N. A., Kuppusamy, U. R. and Vikineswary, S. 2011. Chemical composition and antioxidant properties of extracts of fresh fruiting bodies of Pleurotus sajor-caju (Fr.) Singer. Journal of Agricultural and food chemistry 59: 2618-2626.

Keles, A., Koca, I. and Genccelep, H. 2011. Antioxidant properties of wild edible mushrooms. Journal of Food Processing \& Technology 2: 1-6.

Kore, A.J. 2020. Nutritional and antioxidant significance of selenium enriched mushrooms. Bulletin of the National Research Centre, 44: 34. Https://doi.org/ 10.1186/s42269-020-00289-w

Kris-Etherton, P.M., Hecker, K.D., Bonanome, A., Coval, S.M., Binkoski, A.E. and Hilpert, K.F. 2002. Bioactive compounds in foods: their role in the prevention of cardiovascular disease and cancer. American Journal of Medicine 30: 71-88.

Lakhanpal, T.N., Sai, I. and Thakur, M. 2016. Biodiversity of wild edible, mycorrhizal and neutraceutically important mushrooms. In: Mushrooms in India. Diversity, Improvement, cultivation, Medicinal uses and value addition for rural development (Eds.: Sharma, S., Singh Majil., Prasad Shalinee and Rathore Himanshi). IIT, HanzKhas, New Delhi110016

Lanina, S. A., Toledo, P., Sampels, S., Kamal-Eldin, A. and Jastrebova, J.A. 2007. Comparison of reversedphase liquid chromatography-mass spectrometry with electrospray and atmospheric pressure chemical ionization for analysis of dietary tocopherols. Journal of Chromatography A $\mathbf{1 1 5 7}$ : 159-170.

Lin, S., Lai, T. C., Chen, L., Kwok, H. F., Lau, C. B. and Cheung, P.C.K. 2014. Antioxidant and antiangiogenic properties of phenolic extract from Pleurotus tuberregium. Journal of Agricultural and Food Chemistry 62: 9488-9498. 
Mridu and Atri, N. S. 2015. Podaxis pistillaris - A common wild edible mushroom from Haryana (India) and its Sociobiology. Kavaka 44: 34-37.

Mridu and Atri, N.S. 2017. Nutritional and nutraceutical characterization of three wild edible mushrooms from Haryana, India. Mycosphere 8: 1035-1043.

Natarajan, K. 1979. South Indian Agaricales V: Termitomyces heimii. Mycologia 71 (4): 853-855.

Oke, F. and Aslim, B. 2011. Protective effect of two edible mushrooms against oxidative cell damage and their phenolic composition. Food Chemistry 128: 613619.

Orhan, I. and Üstün, O. 2011. Determination of total phenol content, antioxidant activity and acetylcholinesterase inhibition in selected mushrooms from Turkey. Journal of Food Composition and Analysis 24: 386390.

Ozturk, M., Duru, M. E., Kivrak, S., Mercan-Dogan, N., Turkoglu, A. and Ozler, M. A. 2011. In-vitro antioxidant, anticholinesterase and antimicrobial activity studies on three Agaricus species with fatty acid compositions and iron contents: A comparative study on the three most edible mushrooms. Food and Chemical Toxicology 49: 1353-1360.

Re, R., Pellegrini, N., Proteggente, A., Pannala, A., Yang, M. Rice-Evans, C. 1999. Antioxidant activity applying an improved ABTS radical cation decolorization assay. Free Radical Bio. Med. 26: 1231-1237.

Reis, F.S., Barros, L., Martins, A. and Ferreira, I.C.F.R. 2012.
Chemical composition and nutritional value of the most widely appreciated cultivated mushrooms: an inter-species comparative study. Food Chem. Toxicol. 50: 191-197.

Sarikurkcu, C., Tepe, B., Semiz, D. K. and Solak, M. H. 2010. Evaluation of metal concentration and antioxidant activity of three edible mushrooms from Mugla, Turkey. Food and Chemical Toxicology 48: 12301233.

Savoie, J., Minvielle, N. and Largeteau, M. L. 2008. Radicalscavenging properties of extracts from the white button mushroom, Agaricus bisporus. Journal of the Science of Food and Agriculture 88: 970-975.

Slinkard, K. and Singleton, V.L. 1977. Total phenol analysis: automation and comparison with manual methods. American Journal of Enology and Viticulture 28: 4955.

Soares, A. A., de Souza, C. G. M., Daniel, F. M. and Ferrari, G. P. 2009. Antioxidant activity and total phenolic content of Agaricus brasiliensis (Agaricus blazei Murrill) in two stages of maturity. Food Chemistry 112: $775-781$.

Yim, H. S., Chye, F. Y., Koo, S. M., Matanjun, P., How, S. C. and Ho, C. W. 2012. Optimization of extraction time and temperature for antioxidant activity of edible wild mushroom Pleurotus porrigens. Food and Bioproducts Processing 90: 235-242. 